\title{
Flexural Behavior of Reinforced Concrete Beam Embedded With Lightning Protection Cable
}

\author{
Mustaqqim Abdul Rahim ${ }^{1}$, Abdul Naser Abdul Ghani ${ }^{2}$, Muhammad Arkam Che Munaaim ${ }^{1}$, \\ Zuhayr Md Ghazaly ${ }^{1}$, Ngah Ramzi Hamzah ${ }^{3} \&$ Zulhelmi Zulkeflee ${ }^{1}$
}

\begin{abstract}
Lightning is the natural phenomena that cannot be prevented that can occur any times especially in the country located in equator like Malaysia. In order to protect our building from the damage cause by the high lightning current impact, lightning protection system must be installed into building. One of the methods is to embed the lightning protection cable in the concrete structure by using lightning cable embedded into concrete and clamp with reinforcement bar. The objective of this research is to investigate the flexural strength of concrete beam embedded with lightning protection cable, which the lightning strike were stimulated by high electric current equipment. The high electric current were provided by high current impulse generator and flowed into the concrete cube. 5 different sample of concrete prepared for this research with two control (with and without electric current) and three with electric current $(15 \mathrm{kA}, 30 \mathrm{kA}$ and $45 \mathrm{kA})$. As the result, the additional reinforcement added into the structure beam was increased the performance of the flexural strength and they are no structural performance effect to concrete beam.
\end{abstract}

Keywords-Lightning, Lightning Protection System, High Electric Current, Lightning Cable, Concrete Beam.

\section{INTRODUCTION}

Lightning is natural phenomena that cannot be prevented. The protection against lightning had been increasingly used in the building to protect the building from the direct lightning impact. This lightning can be one of natural cause of injuries to human or damage of the electrical equipment [1]. Malaysia is the country with highest thunderstorm days in the world [2]. It is recorded the country around the equator received higher number of lightning activity including Africa, Southern Asia and South America. Therefore, lightning protection system was created in 20th century to reduce the damage of equipment, fire on structure or the safety of human life from direct lightning strikes. The average thunderstorm days in this region are around 100 to 140 days per year, which could be categorized as one of the highest thunderstorm days in the world. By that reason, there is very important to protect the building, especially the high rise building from the impact of the lightning strikes. In order to create the system to protect this natural phenomenon to the building, Lightning Protection System (LPS) was introduced in 20th century [4]. The main

\footnotetext{
${ }^{1}$ School of Environmental Engineering, University Malaysia Perlis, Malaysia

${ }^{2}$ School of Housing, Building and Planning, University Sains Malaysia, Malaysia

${ }^{3}$ Faculty of Electrical Engineering, University Teknologi MARA Pulau Pinang, Malaysia).
}

goals are to transfer the lightning charge to the ground safely. The lighting protection cable was chosen because this is the common method to transfer the lightning charge to the ground in the building. LPS is needed to reduce the damages of equipment, fire on structure or the safety of human life from direct lightning strikes. LPS can be classified into two categories, external LPS and the internal LPS. For the external LPS, the conductor wire of LPS is bonded externally on the roof structure, wall structure and finally transfers to the ground. As many problems occurred such as damage or stolen of the external LPS, new guidelines of Public Work Department Malaysia [5], allowed the lightning protection cable concealed in the concrete bonded with the steel bars. This method calls the internal LPS. Previously the main research for the LPS is in term of electricity topic such as induced voltage and current from lightning [6], external lightning protection system for main office building in the area with high lightning density [7] and etc. Intensive literature search in establish data base indicated lack of the investigation on the integrity of the structural systems. Previous study and investigations only focused on the physical damage of concrete structure due to lightning strikes [8]. No such data for the performance of concrete structure due to the lightning impact was provided. Therefore the aim of this research is to provide new data on the structural of the concrete structure with the lightning cable.

\section{MATERIALS AND METHODS}

\section{CONCRETE BEAM}

Concrete Beam $1200 \mathrm{~mm}$ length used in this research. The size of the beam is $200 \times 350 \mathrm{~mm}$. The concrete Grade used was Grade 35. The Beam reinforced with 2 no of bar Diameter $16 \mathrm{~mm}$ at the bottom reinforcement and 2 no of bar Diameter $10 \mathrm{~mm}$ at top reinforcement. And the Shear Link diameter 6 $\mathrm{mm}$ used as the Shear Reinforcement at distance $175 \mathrm{~mm}$. Details of the reinforcement arrangement in the Fig. 1. The beam was cured for 28 days after casting before testing process. 


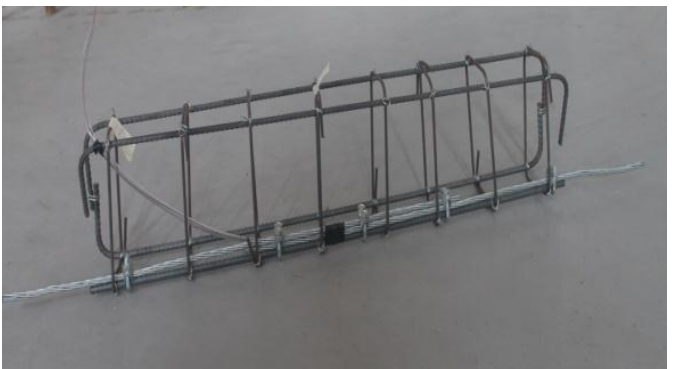

Fig. 1: The Concrete Beam Used

\section{Lightning Protection Cable}

The Cable used in this research is the Galvanized Iron (GI) cable as shown in Fig. 2, as the GI cable was clamp with the reinforcement at the bottom part of the beam and the U-Clamp used to bind the cable and the reinforcement bars to make the combination strong and eliminated the gap distance between the cable and the reinforcement. As the distance may cause worse situation that may will happen during the lightning strike.

\section{LightNing SimULATION TEST}

The lightning simulation test was conducted at Electrical Engineering High Current Laboratory. The electricity current will be routed into the concrete beam using the Impulse Generator which can provide the higher current up to $48 \mathrm{kA}$. According to Public work department guidelines, the lightning impact will be counter starting from $1.5 \mathrm{kA}$. Based on that information, the testing conducted at the three level of current which are $15 \mathrm{kA}$ (Sample 1), $30 \mathrm{kA}$ (Sample 2) and $45 \mathrm{kA}$ (Sample 3) and every sample flowed by 10 times electric current strike to obtained the maximum impact from the high electric current. And finally the beam was transported to Heavy structure laboratory for structural integrity testing after the lightning impact.

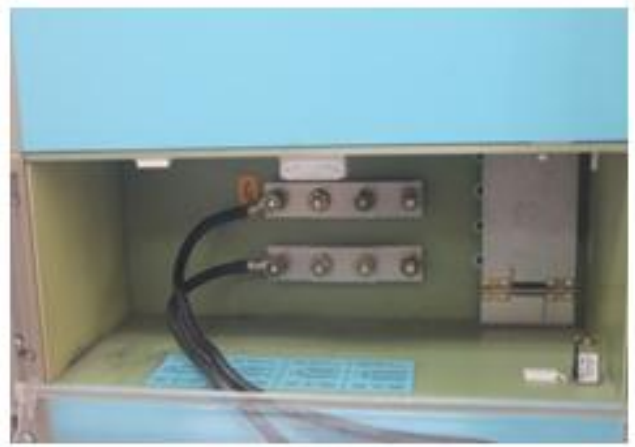

Fig. 3: Impulse Generator for High Current

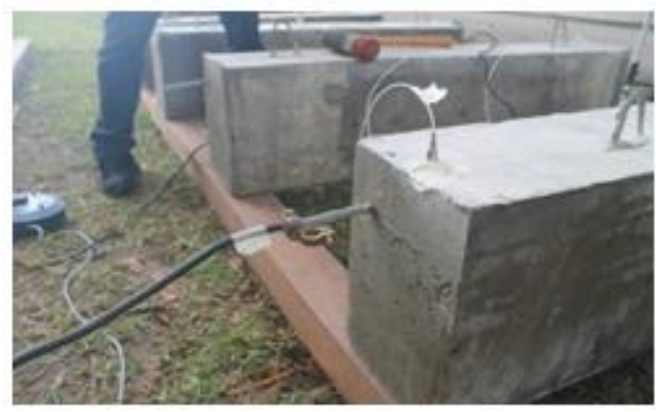

Fig. 4: High Electric Current Routed into Concrete

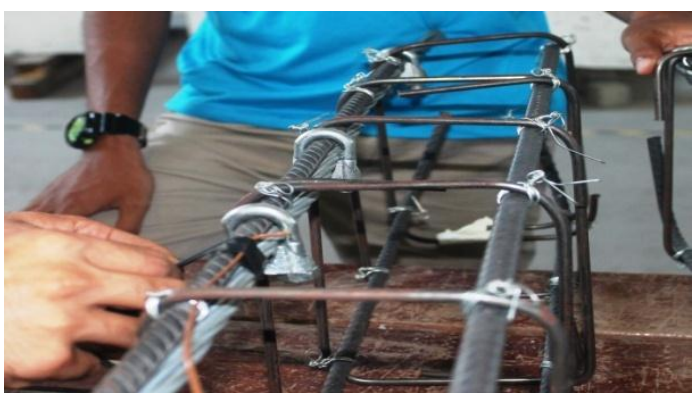

Fig. 2: Lightning Cable and Clamp

FLEXURAL TEST

Three point Flexural testing procedure was used to the concrete beam to obtained the result for the load-displacement and the data was recorded and for analysis. The test was conducted based on the British Standard BS 1881-118 (1983), method for determination of flexural strength. The Linear Variable Displacement Transducer (LVDT) used to record the vertical displacement during the test.

Fig. 5: Flexural Testing Arrangement and LVDT

\section{RESULT AND DISCUSSION}

3.1 MAXimum LOAD AND DisPlacement

TABLE I: MAXIMUM LOAD AND DISPLACEMENT

\begin{tabular}{|l|l|l|}
\hline SAMPLE & \multicolumn{1}{|c|}{$\begin{array}{c}\text { MAXIMUM } \\
\text { LOAD (KN) }\end{array}$} & $\begin{array}{c}\text { MAXIMUM } \\
\text { DISPLACEMENT } \\
\text { (MM) }\end{array}$ \\
\hline $\begin{array}{l}\text { CONTROL } \\
\text { (WITHOUT } \\
\text { CABLE) }\end{array}$ & 120.163 & 15.361 \\
\hline $\begin{array}{l}\text { CONTROL } \\
\text { (WITH } \\
\text { CABLE, } \quad 0 \\
\text { KA) }\end{array}$ & 169.773 & 27.333 \\
\hline $\begin{array}{l}\text { SAMPLE } \quad \mathbf{1} \\
(\mathbf{1 5} \text { KA) }\end{array}$ & 160.64 & 18.838 \\
\hline $\begin{array}{l}\text { SAMPLE } \quad 2 \\
(30 \text { KA) }\end{array}$ & 171.835 & 18.984 \\
\hline $\begin{array}{l}\text { SAMPLE } \quad 3 \\
(45 \text { KA) }\end{array}$ & 165.789 & 17.19 \\
\hline
\end{tabular}

From Table 1, the sample without additional reinforcement cable showed lowest maximum load $(120.163 \mathrm{kN})$ compare to others with cable and lightning current, the value of maximum load is ranging between $160 \mathrm{kN}$ until $171 \mathrm{kN}$. The increment of the load is about $40 \%$ from the original load. This is due to the additional cables which increased the number of reinforcement and make the beam stronger and able to resist more loads before reach the ultimate condition. For the displacement of concrete beam, the maximum peak load increased compared with the beam with and without additional cable. The maximum deflection is $15.361 \mathrm{~mm}$ for control without cable and sample with cable is in the range of 17 until $27 \mathrm{~mm}$. The increment of deflection is in-line with the 
increment of maximum load resulted from the additional 3.2 LOAD - DISPLACEMENT ANALYSIS reinforcement installed.

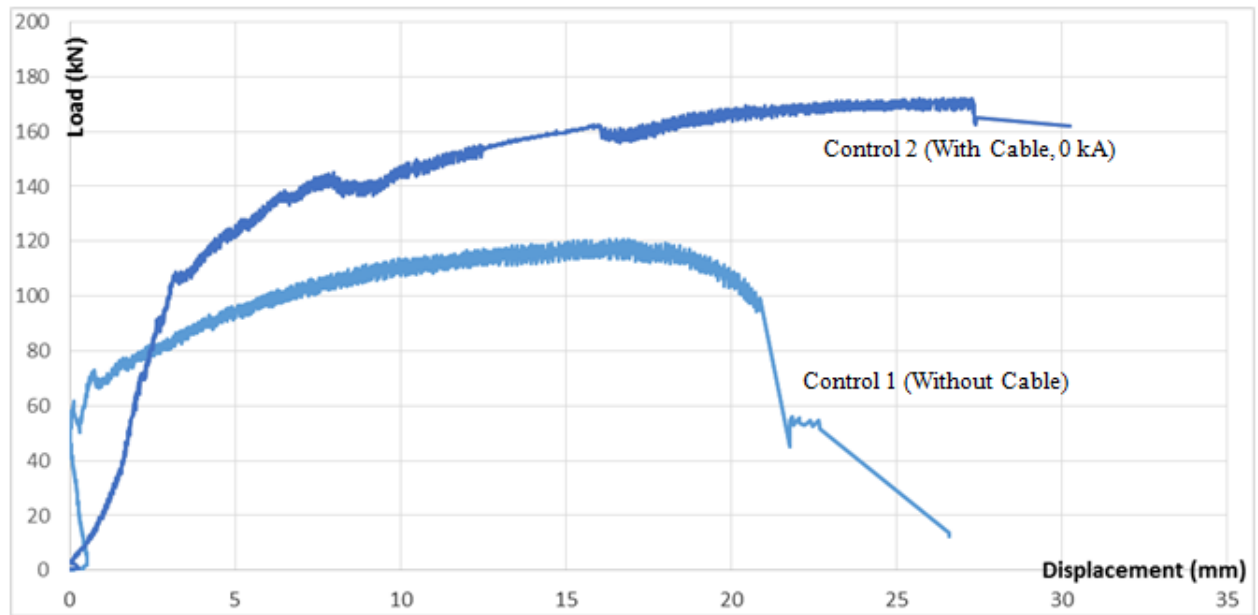

Fig. 5: Load-Displacement Graph for Control Sample with Cable and without Cable

For the result in Fig. 5, the behaviour of load-displacement of beam with and without lightning cable showed different pattern of graph. The Control 1 beam reached highest load with less displacement at the beginning of the graph, meanwhile the Control 2 beam proportional increased the graph at the initial phase

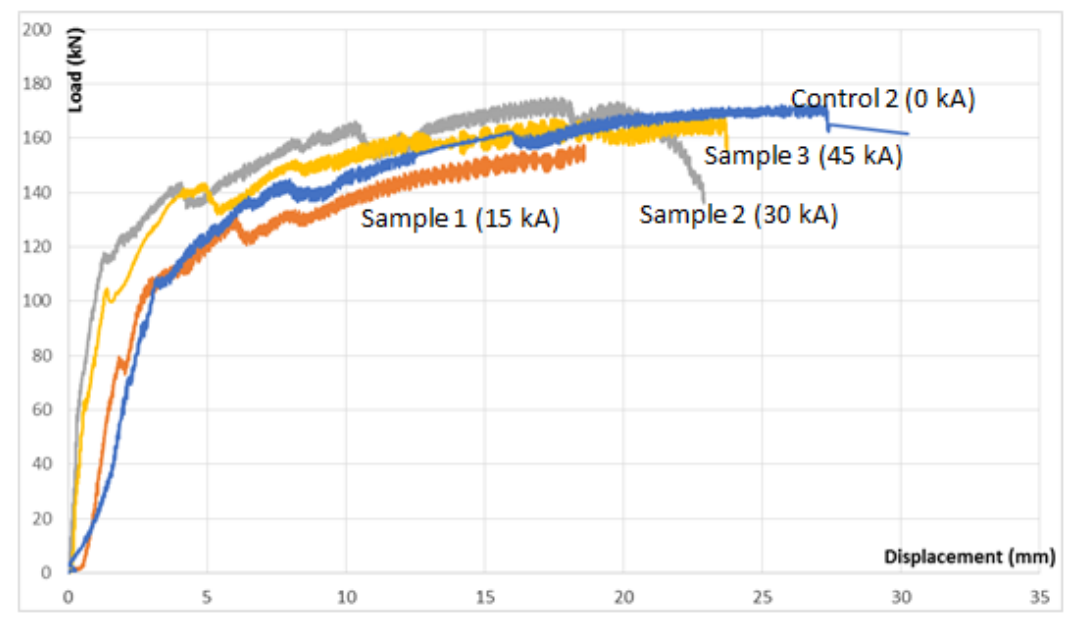

Fig. 6: Load-Displacement Graph for Beam with Lightning Cable

Control 1 reached the first peak load at $60 \mathrm{kN}$ and Control 2 at $110 \mathrm{kN}$ and the highest maximum load before failure at $120 \mathrm{kN}$ and $169 \mathrm{kN}$ respectively. Both load increased pattern showed almost same pattern at the initial and final maximum load, which increasing about $40 \%$ of load. The increment is due to the additional lightning cables which improve the overall structure performance of the beam. For the Graph in Fig. 6 is the relationship of load-displacement for Beams with Lightning Cable. Comparing the pattern between the beams, is shown slightly difference between the patterns. The entire sample has increased proportional at the initial phase of the Graph and the initial peak load is around 100 to $120 \mathrm{kN}$. The Sample 1 has the lowest reading of the maximum load, and the sample 3 obtained the highest value of the final peak load, $171.835 \mathrm{kN}$. Meanwhile the control sample 2 reached the maximum deflection on this research. Based on this data, it can be concluded that the electric current flowed into the concrete beam which passed thru the lightning cable doesn't not have any significant to the overall strength of the concrete beam. The clearly difference in pattern as in Fig. 5 indicated that the additional reinforcement from the lightning cable improve the capacity of tension reinforcement as the location of the installation of the lightning cable at the bottom reinforcement of the concrete beam. The concrete beams are safe to be installed with the lightning cable if all precautions are counted into consideration.

\section{ACKNOWLEDGEMENTS}

This research was funded by Fundamental Research Grant Scheme Phase 2/2014(9003-00484). The authors wish to extend appreciation to Ministry of High Education Malaysia, School of Environmental Engineering University Malaysia Perlis, School of Housing Building \& Planning University Sains Malaysia, and University Teknologi MARA Pulau Pinang Malaysia. 


\section{REFERENCES}

[1] Zoro, R , "External Lightning Protection System for Main Office Building in the Area with High Lightning Density". ICEEI 2013.

[2] Mustaqqim Abdul Rahim, The Temperature Effect to the Concrete Due to the Single Strike of High. NJ: Materials Science Forum, Trans Tech Publications, Switzerland 2016.

[3] Eritech, Lightning protection Handbook. Erico 2009.

[4] F.Heidler et all. Parameters of lightning current. 28th International on Lightning Protection. 2008

[5] Public Work Department, Specification For Lightning Protection System for Structures in Malaysia. Revision 1. 2011

[6] Masuru, Induced voltages and currents on electrical wirings in building directly hit by lightning. Electric Power Systems Research 85. 2012

[7] Zoro, R , External Lightning Protection System for Main Office Building in the Area with High Lightning Density. The $4^{\text {th }}$ International Conference on Electrical Engineering and Informatics (ICEEI 2013). https://doi.org/10.1016/j.protcy.2013.12.319

[8] Kokkinos et all, Effect of Direct Lightning strikes in the Down Conductors Embedded in Reinforcement. 28th International on Lightning Protection.2006 